\title{
ANALISIS PENGARUH INFLASI, NILAI TUKAR DAN BI RATE TERHADAP TABUNGAN MUDHARABAH PADA PERBANKAN SYARIAH DI INDONESIA
}

\author{
Zakaria Batubara, Eko Nopiandi \\ Sekolah Tinggi Ilmu Ekonomi (STIE) Syariah Bengkalis \\ zakariabatubara@yahoo.co.id, eko.nopiandi24@gmail.com
}

\begin{abstract}
This research aims to determine the effect of inflation, exchange rates, and the BI Rate on mudharabah savings in Islamic banking in Indonesia partially and simultaneously. This research is a quantitative study with time series data. The data used in this study are secondary data. The population in this study is inflation data, the rupiah exchange rate, and the BI Rate and mudharabah savings. The population of Islamic banks in this study totaled 34 Islamic banks. The data analysis technique used in this study is multiple regression analysis. Partially, inflation, exchange rates or the rupiah exchange rate and the BI Rate have a positive effect on mudharabah savings in Islamic banking in Indonesia. Simultaneously the inflation variable, the exchange rate or the rupiah exchange rate and the BI Rate have a significant effect on mudharabah savings in Islamic banking in Indonesia with an influence of $88.6 \%$.
\end{abstract}

Keywords: Inflation, Exchange Rates, BI Rate, Mudharabah Savings, Islamic Banking.

\begin{abstract}
ABSTRAK
Penelitian bertujuan untuk mengetahui pengaruh inflasi, nilai tukar, dan BI Rate terhadap tabungan mudharabah pada perbankan syariah di Indonesia secara parsial dan simultan. Penelitian ini adalah penelitian kuantitatif dengan data time series. Data yang digunakan pada penelitian ini adalah data sekunder. Populasi dalam penelitian ini adalah data inflasi, nilai tukar rupiah, dan BI Rate dan tabungan mudharabah. Adapun populasi bank syariah dalam penelitian ini berjumlah total 34 bank syariah. Teknik analisis data yang digunakan dalam penelitian ini adalah analisis regresi berganda. Secara parsial variabel inflasi, nilai tukar atau kurs rupiah dan BI Rate berpengaruh positif terhadap tabungan mudharabah pada perbankan syariah di Indonesia. Secara simultan variabel inflasi, nilai tukar atau kurs rupiah dan BI Rate berpengaruh signifikan terhadap tabungan mudharabah pada perbankan syariah di Indonesia dengan pengaruh sebesar $88,6 \%$.
\end{abstract}

Kata Kunci: Inflasi, Nilai Tukar, BI Rate, Tabungan Mudharabah, Perbankan Syariah.

\section{PENDAHULUAN}

Bank syariah adalah suatu lembaga keuangan yang usaha pokoknya memberikan kredit, pembiayaan dan jasa-jasa lainnya dalam lalu lintas 
pembayaran serta peredaran uang yang pengoperasiannya disesuaikan dengan prinsip-prinsip Islam (UU No. 21/2008). Bank syariah didirikan dengan tujuan untuk mempromosikan dan mengembangkan penerapan prinsip-prinsip Islam sesuai Al-Qur'an dan Al-Hadist, tradisinya dalam transaksi keuangan dan perbankan serta bisnis lain yang terkait. Prinsip-prinsip utama yang diikuti oleh bank Islam adalah larangan riba (suku bunga) dalam berbagai bentuk transaksi, melakukan kegiatan usaha dan perdagangan berdasarkan perolehan keuntungan yang sah dan sesuai kesepakatan bersama.

Salah satu produk yang ditawarkan oleh perbankan syariah adalah dengan menggunakan akad mudharabah. Secara sederhana, pengertian mudharabah adalah teransaksi penanaman dana dari pemilik dana (shahibul maal) kepada pengelola dana (mudharib) untuk melakukan kegiatan usaha tertentu yang sesuai syariah, dengan pengambilan hasil usaha antara kedua belah pihak berdasarkan nisbah yang telah disepakati sebelumnya (Muhammad 2014).

Dalam makro ekonomi sering kali suku bunga dan laju inflasi berkaitan erat dan merupakan pilihan yang dilematis bagi penentu kebijakan pembangunan. Di satu pihak inflasi dianggap sebagai sumber penurunan daya beli yang terjadi karena jumlah uang yang beredar terlalu besar, sehingga untuk menangkalnya harus mengurangi jumlah uang yang beredar. Di lain pihak pengurangan jumlah uang yang beredar akan menimbulkan tingginya tingkat suku bunga. Akibat lebih lanjut tingginya tingkat suku bunga akan mengakibatkan macetnya investasi, hilangnya kesempatan kerja, menurunnya pertumbuhan ekonomi, berkurangnya kesejahteraan sosial serta penderitaan bagi usaha-usaha kecil peminjam dana.

Pada tataran makro, nilai uang terhadap barang memiliki peran penting terhadap jumlah tabungan masyarakat di bank. Tingginya inflasi akan menurunkan nilai kekayaan dalam bentuk uang. Inflasi merupakan salah satu peristiwa moneter yang sangat penting dan hampir semua negara mengalaminya baik negara miskin, berkembang atau bahkan negara maju sekalipun tidak dapat lepas dari masalah ini. Apabila terjadi inflasi maka terjadi ketidakpastian kondisi makro ekonomi suatu negara yang mengakibatkan masyarakat lebih menggunakan dananya untuk konsumsi atau investasi dalam bentuk lain, misalnya saja investasi emas. Tingginya harga dan pendapatan yang tetap atau pendapatan meningkat sesuai dengan besarnya inflasi membuat masyarakat tidak mempunyai kelebihan dana untuk disimpan dalam bentuk tabungan atau diinvestasikan.

Faktor lain yang mempengaruhi jumlah tabungan mudharabah adalah nilai kurs rupiah terhadap dollar AS. Secara umum, apabila sesuatu barang ditukar dengan barang lain tentu didalamnya terdapat perbandingan nilai tukar antara keduanya. Nilai tukar itu sebenarnya merupakan semacam harga didalam pertukaran tersebut. Demikian pula pertukaran antara dua mata uang yang berbeda, maka akan terdapat perbandingan nilai atau harga antara kedua mata uang tersebut. Perbandingan nilai inilah yang sering disebut dengan kurs (exchange rate).

Selain itu juga, suku bunga mempunyai peranan yang sangat penting dalam perekonomian, karena suku bunga merupakan salah satu faktor yang dapat mempengaruhi perekonomian secara makro. Suku bunga mencerminkan biaya yang harus dikeluarkan untuk meminjam sejumlah dana serta pendapatan yang diperoleh karena meminjam dana tersebut. Tabungan menurut pandangan ekonomi klasik, merupakan fungsi dari tingkat bunga. Tingkat bunga yang tinggi 
akan semakin mendorong seseorang untuk menabung dan mengorbankan konsumsi sekarang untuk dimanfaatkan bagi konsumsi di masa yang akan datang. Tentu saja konsep ini berbeda dengan sistem perbankan syariah yang menggunakan sistem bagi hasil atas penggunaan dana oleh pihak peminjam (baik oleh pihak nasabah atau bank).

Tujuan dari penelitian ini adalah untuk mengetahui pengaruh inflasi, nilai tukar, dan BI Rate secara parsial terhadap tabungan mudharabah pada perbankan syariah di Indonesia. Kemudian untuk mengetahui pengaruh inflasi, nilai tukar, dan BI Rate secara simultan terhadap tabungan mudharabah pada perbankan syariah di Indonesia.

\section{TELAAH LITERATUR}

\section{Tabungan}

Tabungan adalah simpanan yang penarikannya hanya dapat dilakukan menurut syarat tertentu yang disepakati, tetapi tidak dapat ditarik dengan cek/bilyet giro, dan/atau alat lainnya yang dipersamakan dengan itu (Muhammad 2014, 35). Tabungan juga diartikan sebagai salah satu bentuk simpanan (funding) yang dananya disimpan pada suatu rekening yang setiap saat dan kapan saja pemilik tabungan dapat menarik uangnya baik tunai maupun nontunai (pindah buku, transfer ke bank lain) melauli mesin ATM atu teller (Supriyono 2011, 24).

Berdasarkan Undang-Undang No 21 tahun 2008 tentang perbankan syariah, tabungan adalah simpanan berdasarkan akad wadi'ah atau investasi dana berdasarkan akad mudharabah atau akad lain yang tidak bertentangan dengan prinsip syariah yang penarikannya hanya dapat dilakukan menurut syarat dan ketentuan tertentu yang disepakati, tetapi tidak dapat ditarik dengan cek, bilyet giro dan/atau alat lainnya yang dipersamakan dengan itu.

Tabungan mempunyai dua unsur, yaitu (Hermansyah 2011, 48-49): (a) Penarikannya dengan syarat tertentu, yang berarti bahwa simpanan dalam bentuk tabungan hanya dapat ditarik sesuai dengan persyaratan tertentu yang telah disepakati oleh nasabah penyimpan dan bank. Misalnya, ada persyaratan bahwa nasabah penyimpan dapat melakukan penarikan simpanan setiap waktu baik dalam jumlah yang dibatasi atau tidak dibatasi, atau penarikannya hanya dapat dilakukan dalam suatu jangka waktu tertentu. (b) Cara penarikannya. Dalam hal ini penarikan simpanan dalam bentuk tabungan dapat dilakukan secara langsung oleh sinasabah penyimpan atau orang lain yang dikuasakan olehnya dengan mengisi slip penarikan yang berlaku di bank yang bersangkutan. Namun demikian, penarikannya tidak dapat dilakukan dengan menggunakan cek, bilyet giro, dan/atau alat lainnya yang dipersamakan dengan itu.

Tabungan syariah adalah tabungan yang dijalankan berdasarkan prinsipprinsip syariah. Dalam hal ini, Dewan Syariah Nasional (DSN) telah mengeluarkan fatwa yang menyatakan bahwa tabungan yang dibenarkan adalah tabungan yang berdasarkan prinsip wadiah dan mudharabah (Karim 2010, 357).

\section{Mudharabah}

Mudharabah adalah akad yang telah dikenal oleh umat Muslim sejak zaman nabi, bahkan telah dipraktikan oleh bangsa Arab sebelum turunnya Islam. Ketika Nabi Muhammad Saw. Berprofesi sebagai pedagang, ia melakukan akad 
mudharabah dengan Khadijah. Dengan demikian, ditinjau dari segi hukum islam, maka praktik mudharabah ini dibolehkan, baik menurut Al-Qur'an, Hadist, maupun Ijma' (Karim 2010, 204). Mudharabah juga diartikan sebagai suatu akad atau perjanjian antara dua orang atau lebih, dimana pihak pertama memberikan modal usaha, sedangkan pihak lain menyediakan tenaga dan keahlian, dengan ketentuan bahwa keuntungan dibagi di antara mereka sesuai dengan kesepakatan yang mereka telah tetapkan bersama (Muslich 2015, 366).

Al-Mudharabah adalah akad perjanjian antara dua pihak atau lebih untuk melakukan kerjasama usaha. Satu pihak akan menempatkan modal sebesar $100 \%$ yang disebut dengan shahibul maal, dan pihak lainnya sebagai pengelola usaha, disebut dengan mudharib. Bagi hasil dari usaha yang dikerjasamakan dihitung sesuai dengan nisbah yang disepakati antara pihak-pihak yang bekerjasama (Ismail 2011, 83).

Para ulama mazhab sepakat bahwa mudharabah hukumnya dibolehkan berdasarkan Al-Quran, Sunnah, ijma' dan qiyas. Adapun dasar hukum yang memperbolehkannya akad mudharabah adalah:

Surat Al-Jumu'ah ayat 10:

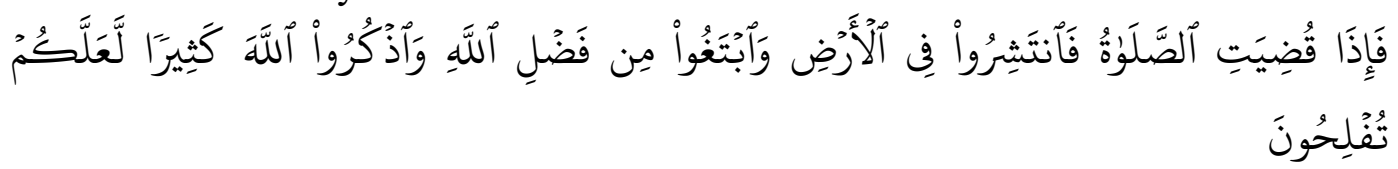

Artinya: "Apabila telah ditunaikan shalat, maka bertebarlah dimuka bumi dan carilah karunia Allah SWT dan ingatlah Allah banyak-banyak supaya kamu beruntung" (Kemenag 2010).

Surat Al-Baqarah ayat 198:

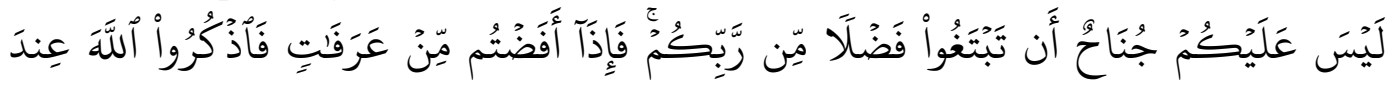

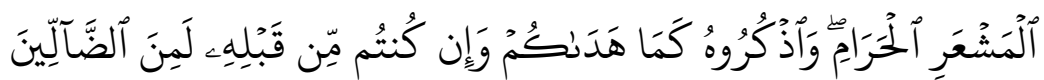

Artinya: "Tidak ada dosa bagimu untuk mencari karunia (rezeki hasil perniagaan dari tuhanmu. Maka apabila kamu telah bertolak dari 'Arafat, berdzikirlah kepada Allah di Masy'arilharam. Dan berdzikirlah (dengan menyebut) Allah sebagaimana yang ditunjukkan-Nya kepadamu; dan sesungguhnya kamu sebelum itu benar-benar termasuk orang-orang yang sesat" (Kemenag 2010).

Hadis Rasulullah Saw. yang diriwayatkan oleh Thabrani dalam al-Autsah dari Ibnu Majah:

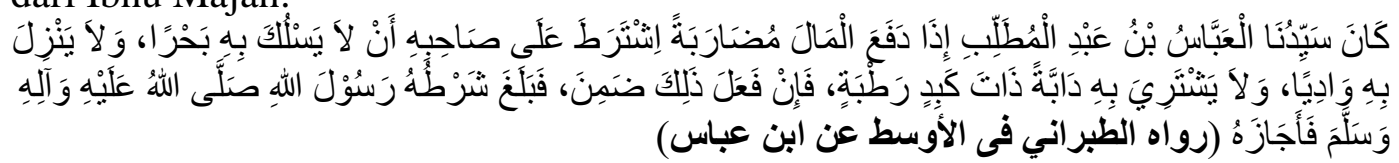
Artinya: "Diriwayatkan dari Ibnu Abbas, bahwa Abbas bin Abdul Muthalib: jika memberikan dana ke mitra usahanya secara tidak dibawa mengarungi lautan, menuruni lembah yang berbahaya, atau membeli ternak yang berparu-paru basah. Jika melayani peraturan tersebut, maka yang bersangkutan bertanggung jawab atas dana tersebut. Disampaikanlah syarat-syarat tersebut kepada Rasulullah Saw dan Rasulullah pun memperbolehkannya”.

Rukun akad mudharabah menurut Hanafiah adalah ijab dan qabul, dengan menggunakan lafal yang menunjukkan kepada arti mudharabah. Lafal yang digunakan untuk ijab adalah lafal mudharabah, muqarradah, dan mu'amalah, serta lafal-lafal lain yang artinya sama dengan lafal-lafal tersebut. Adapun lafal 
qabul yang digunakan oleh amil mudharib (pengelola) adalah lafal: "saya ambil", atau "saya terima", atau "saya setujui", dan semacamnya. Menurut jumhur ulama, rukun mudharabah ada tiga, yaitu: (1) 'Aqid, yaitu pemilik modal dan pengelola (amil mudharib ), (2) Ma'qud 'alaih, yaitu modal, tenaga (pekerjaan) dan keuntungan, (3) Shighat, yaitu ijab dan qabul. Sedangkan Syafi'iyah menyatakan bahwa rukun mudharabah ada lima, yaitu: (1) Modal, (2) Tenaga (pekerjaan), (3) Keuntungan, (4) Shighat, dan (5) Aqidain (Muslich 2015).

\section{Tabungan Mudharabah}

Yang dimaksud dengan tabungan mudharabah adalah tabungan yang dijalankan berdasarkan akad mudharabah. Seperti yang telah dikemukakan sebelumnya, mudharabah memiliki dua bentuk, yakni mudharabah mutlaqah dan mudharabah muqayyadah, yang perbedaan utama diantara keduanya terletak pada ada atau tidaknya persyaratan yang diberikan pemilik dana kepada bank dalam mengelola hartanya (Karim 2010, 347).

Bagi hasil tabungan mudharabah sangat dipengaruhi oleh antara lain: (a) Pendapatan bank syariah. (b) Total investasi mudharabah mutlaqah. (c) Total investasi tabungan mudharabah. (d) Rata-rata saldo tabungan mudharabah. (e) Nisbah tabungan mudharabah yang ditetapkan sesuai dengan perjanjian. (f) Metode perhitungan bagi hasil yang diberlakukan. (g) Total pembiayaan bank syariah. Dalam memperhitungkan bagi hasil tabungan mudharabah, hal-hal yang perlu diperhatikan adalah sebagai berikut: (a) Hasil perhitungan bagi hasil dalam angka satuan bulat tanpa mengurangi hak nasabah (pembulatan ke atas untuk nasabah dan pembulatan ke bawah untuk bank). (b) Hasil perhitungan pajak dibulatkan ke atas sampai puluhan terdekat. Dalam hal pembayaran bagi hasil, bank syariah menggunakan metode end of month (Ismail 2011, 89).

\section{Inflasi}

Inflasi adalah kenaikan harga barang-barang yang bersifat umum dan terus-menerus (Rahardja 2008, 359). Secara umum inflasi dapat diartikan sebagai kenaikan tingkat harga secara umum dari barang/komoditas dan jasa selama suatu priode waktu tertentu. Inflasi dapat dianggap sebagi fenomena moneter karena terjadinya penurunan nilai unit penghitungan moneter terhadap suatu komoditas. Sebaliknya, jika yang terjadi adalah penurunan nilai unit penghitungan moneter terhadap barang-barang/komoditas dan jasa didefinisikan sebagai deflasi (deflation) (Karim 2014, 135).

Seperti sebuah penyakit, inflasi dapat digolongkan menurut tingkat keparahannya, yaitu: (1) Moderate inflation, karakteristiknya adalah kenaikan tingkat harga yang lambat. Umumnya disebut sebagi "inflasi satu digit". Pada tingkat inflasi seperti ini orang-orang masih mau untuk memegang uang dan menyimpan kekayaannya dalam bentuk uang daripada dalam bentuk aset riil. (2) Galloping Inflation, inflasi pada tingkat ini terjadi pada tingkatan $20 \%$ sampai dengan $200 \%$ pertahun. Pada tingkatan seperti ini orang-orang hanya mau memegang uang seperlunya saja, sedangkan kekayaan disimpan dalam bentuk aset-aset riil. (3) Hyper Inflation, inflasi jenis ini terjadi pada tingkatan yang sangat tinggi yaitu jutaan sampai trilyunan persen per tahun. Walapun sepertinya pemerintahan yang perekonomiannya dapat bertahan menghadapi galloping 
inflation, akan tetapi tidak ada pemerintahan yang dapat bertahan menghadapi inflasi jenis ketiga yang amat 'mematikan' ini (Karim 2014, 137).

\section{Nilai Tukar (Kurs)}

Kurs valuta asing atau nilai tukar didefinisikan sebagai jumlah uang domestik yang dibutuhkan, yaitu banyaknya rupiah yang dibutuhkan untuk memperoleh satu unit mata uang asing. Kurs (nilai tukar) valuta asing juga dapat diartikan sebagai harga mata uang negara asing dalam satuan mata uang domestik (Sukirno 2011, 397). Exchange rate (nilai tukar) atau yang lebih populer dikenal dengan nama kurs mata uang adalah catatan (quotation) harga pasar dari mata uang asing (foreign currency) dalam harga mata uang domestik (domestic currency), begitu pula sebaliknya, yaitu harga mata uang domestik dalam mata uang asing. Nilai tukar uang menggambarkan tingkat harga pertukaran dari satu mata uang ke mata uang yang lainnya dan digunakan dalam berbagai transaksi, antara lain transaksi perdagangan internasional, ataupun aturan uang jangka pendek antar negara yang melewati batas-batas geografis ataupun batas-batas hukum (Al-Arif 2010, 107).

Nilai tukar suatu mata uang dapat ditentukan oleh pemerintah (otoritas moneter) seperti pada negara-negara yang memakai sistem fixed exchange rates ataupun ditentukan oleh kombinasi antara kekuatan-kekuatan pasar yang saling berinteraksi (bank komersial - perusahaan multinasional - perusaan manajemen aset - perusahaan asuransi - bank devisa - bank sentral) serta kebijakan pemerintah seperti negara-negara yang memakai rezim sistem "flexible exchange rates" (Karim 2014, 157).

Sejarah mencatat, dalam sistem moneter Internasional pernah dikenal tiga macam sistem nilai tukar mata uang (kurs valas). Tiga sistem tersebut adalah: sistem nilai tukar tetap (fixed exchange rate system), sistem nilai tukar mengambang (floating exchange rate system) dan sistem nilai tukar yang dikaitkan (pagged exchange rate system) (Al-Arif 2010).

Perubahan dalam permintaan dan penawaran suatu valuta, yang selanjutnya menyebabkan perubahan dalam kurs valuta, disebabkan oleh banyak faktor. Yang terpenting diantaranya adalah sebagai berikut: perubahan dalam citarasa masyarakat, perubahan harga baran ekspor dan impor, kenaikan harga umum (inflasi) dan perubahan suku bunga dan tingkat pengembalian investasi (Sukirno 2011, 417).

\section{BI Rate}

Menurut Bank Indonesia, BI Rate adalah suku bunga kebijakan yang mencerminkan sikap atau stance kebijakan moneter yang ditetapkan oleh Bank Indonesia dan diumumkan kepada publik (BI 2015). BI Rate merupakan indikasi suku bunga jangka pendek yang diinginkan Bank Indonesia dalam upaya mencapai target inflasi. BI Rate digunakan sebagai acuan dalam operasi moneter untuk mengarahkan agar suku bunga Sertifikat Bank Indonesia (SBI) 1 bulan hasil lelang operasi pasar terbuka berada disekitar BI Rate. Selanjutnya suku bunga BI diharapkan mempengaruhi Pasar Uang Antar Bank (PUAB), suku bunga pinjaman, dan suku bunga lainnya dalam jangka panjang.

BI Rate diumumkan oleh dewan gubernur Bank Indonesia setiap rapat dewan gubernur bulanan dan diimplementasikan pada operasi moneter yang 
dilakukan Bank Indonesia melalui pengelolaan likuiditas (liquidity management) di pasar uang untuk mencapai sasaran operasional kebijakan moneter.

Respon kebijakan moneter dinyatakan dalam perubahan BI Rate (secara konsisten dan bertahap dalam kelipatan 25 basis poin (bps). Dalam kondisi untuk menunjukkan intensi Bank Indonesia yang lebih besar terhadap pencapaian sasaran inflasi, maka perubahan BI Rate dapat dilakukan lebih dari 25 bps dalam kelipatan 25 bps.

Dari uraian teori di atas maka dapat dirumuskan hipotesis yaitu: Hipotesis pertama terdapat pengaruh antara inflasi terhadap tabungan mudharabah pada perbankan syariah di Indonesia. Hipotesis kedua terdapat pengaruh antara kurs terhadap tabungan mudharabah pada perbankan syariah di Indonesia. Hipotesis ketiga terdapat pengaruh antara BI rate terhadap tabungan mudharabah pada perbankan syariah di Indonesia. Hipotesis keempat terdapat pengaruh antara inflasi, kurs dan BI rate secara simultan terhadap tabungan mudharabah pada perbankan syariah di Indonesia.

\section{METODE PENELITIAN}

Penelitian ini adalah penelitian kuantitatif dengan data time series. Data yang digunakan pada penelitian ini adalah data sekunder. Populasi dalam penelitian ini adalah data inflasi, kurs, dan BI rate dan tabungan mudharabah. Adapun populasi bank syariah dalam penelitian ini berjumlah total 34 bank syariah, yang terdiri dari 12 Bank Umum Syariah (BUS) dan 22 Unit Usaha Syariah (UUS). Metode penentuan sampel yang digunakan dalam penelitian ini adalah Purposive Sample, dimana populasi dijadikan sebagai sampel, sehingga sampel penelitian ini adalah data inflasi, kurs, dan BI rate dan tabungan mudharabah.

Data yang gunakan dalam penelitian ini adalah data kuantitatif yang berbentuk data rasio. Data diperoleh dari data bulanan historis inflasi, kurs, BI rate dan tabungan mudharabah yang diperoleh dari situs resmi Bank Indonesia dan situs resmi Otoritas Jasa Keuangan (OJK). Teknik pengumpulan data yang digunakan dokumentasi dan studi pustaka. Teknik analisis data yang digunakan dalam penelitian ini adalah analisis regresi berganda. Dalam penggunaan regresi berganda dilakukan dengan berbagai macam uji, yaitu: uji asumsi klasik (normalitas, mulktikolinearitas, homogenitas, autokorelasi dan linearitas) dan uji statistik (uji regresi linear berganda, uji t, uji f dan uji koefisien determinan).

\section{HASIL DAN PEMBAHASAN PENELITIAN}

\section{Perkembangan Tabungan Mudharabah}

Tabungan mudharabah merupakan salah satu jenis simpanan pada bank syariah yang mempengaruhi besarnya total Dana Pihak Ketiga Syariah. Hal ini dimungkinkan karena tabungan sebagai salah satu komponen yang paling banyak digunakan oleh masyarakat.

Tabungan mudharabah ini adalah tabungan yang berdasarkan prinsip mudharabah muthlaqah. Dimana Bank Syariah mengelola dana yang diinvestasikannya oleh penabung secara produktif, menguntungkan dan memenuhi prinsip-prinsip syariah islam. Hasil keuntungannya akan dibagikan kepada penabung dan bank sesuai perbandingan bagi hasil atau nisbah yang 
disepakati bersama. Apabila tabungan hanya ditimbun tanpa diinvestasikan, hal tersebut bagaikan harta yang tidak berguna karena Islam tidak menyukai adanya tindakan penimbunan harta yang sia-sia atau tidak diinvestasikan.

Dana pihak ketiga tabungan mudharabah di sini adalah kumpulan dana yang diperoleh dari nasabah, dalam arti nasabah sebagai masyarakat, individu, perusahaan, koperasi, yayasan, dan lain-lain baik dalam mata uang rupiah maupun valuta aing yang dialokasikan atau dikelola oleh perbankan syariah dan kemudian keuntungan tersebut akan dibagi antara kedua belah pihak baik bank dan nasabah.

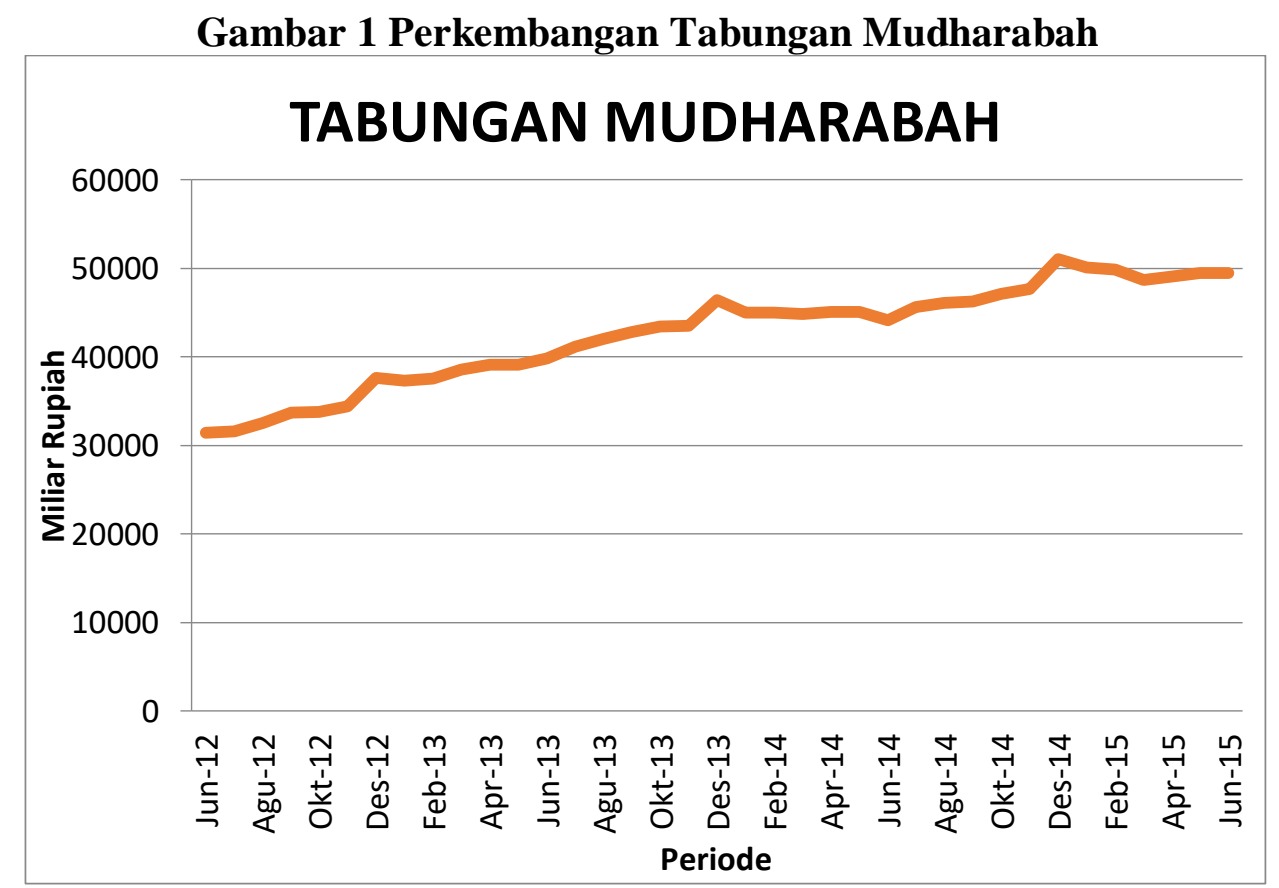

Sumber: Otoritas Jasa Keuangan (Olahan peneliti)

Gambar 1 di atas dapat diketahui bahwa tabungan mudharabah tertinggi berada pada bulan Desember 2014 sebesar Rp. 51.020 milyar dan terendah terjadi pada bulan Juni 2012 sebesar Rp. 31.466 milyar. Selama periode perkembangannya, tabungan mudharabah cenderung meningkat setiap bulannya meskipun sempat mengalami penurunan pada bulan-bulan tertentu. Hal tersebut diperkirakan karena para nasabah lebih nyaman untuk dapat mengambil kapan saja uangnya, dibandingkan mendepositokan uangnya dalam jangka waktu tertentu. Dan hal ini berdampak positif bagi perkembangan dana pihak ketiga khususnya tabungan mudharabah.

\section{Perkembangan Inflasi}

Secara umum inflasi dapat diartikan sebagai kenaikan tingkat harga secara umum dari barang/komoditas dan jasa selama suatu periode waktu tertentu. Inflasi dapat dianggap sebagai fenomena moneter karena terjadinya penurunan nilai unit penghitungan moneter terhadap suatu komoditas. Inflasi merupakan salah satu variabel makro yang sangat berpengaruh dan menjadi masalah bagi perekonomian suatu negara. Inflasi yang mengalami kenaikan terus-menerus akan menyebabkan ketidakstabilan yang akan memperburuk kinerja perekonomian suatu negara. 


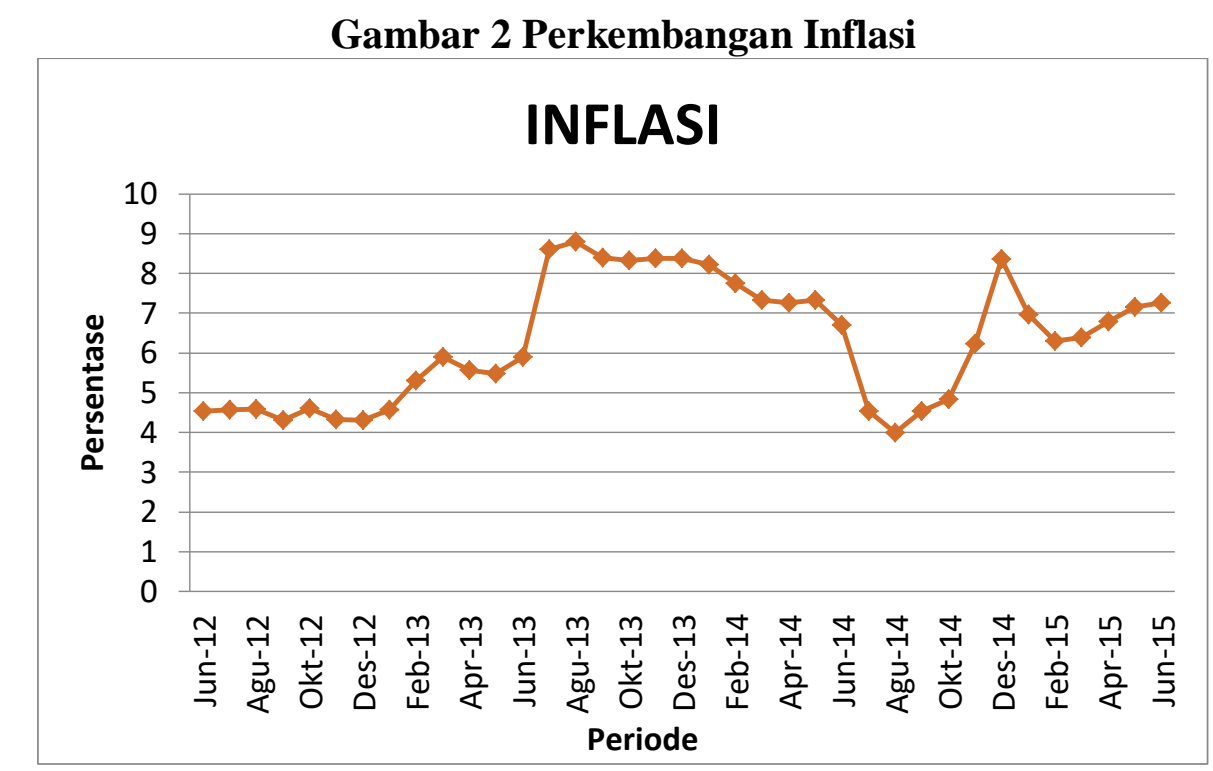

Sumber: Bank Indonesia (Olahan peneliti)

Gambar 2 di atas dapat diketahui bahwa perkembangan inflasi tertinggi terjadi pada bulan Agustus 2013 sebesar 8,79 \% dan inflasi terendah terjadi di bulan Agustus 2014 sebesar 3,99 \%. Secara keseluruhan inflasi mengalami fluktuasi dan cendering mengalami kanaikan dari setiap tahunnya.

\section{Perkembangan Nilai Tukar (Kurs)}

Data Nilai Tukar Rupiah yang digunakan dalam penelitian ini adalah antara harga jual dan harga beli dollar AS yang dinyatakan dalam satuan unit rupiah.

\section{Gambar 3 Perkembangan Nilai Tukar}

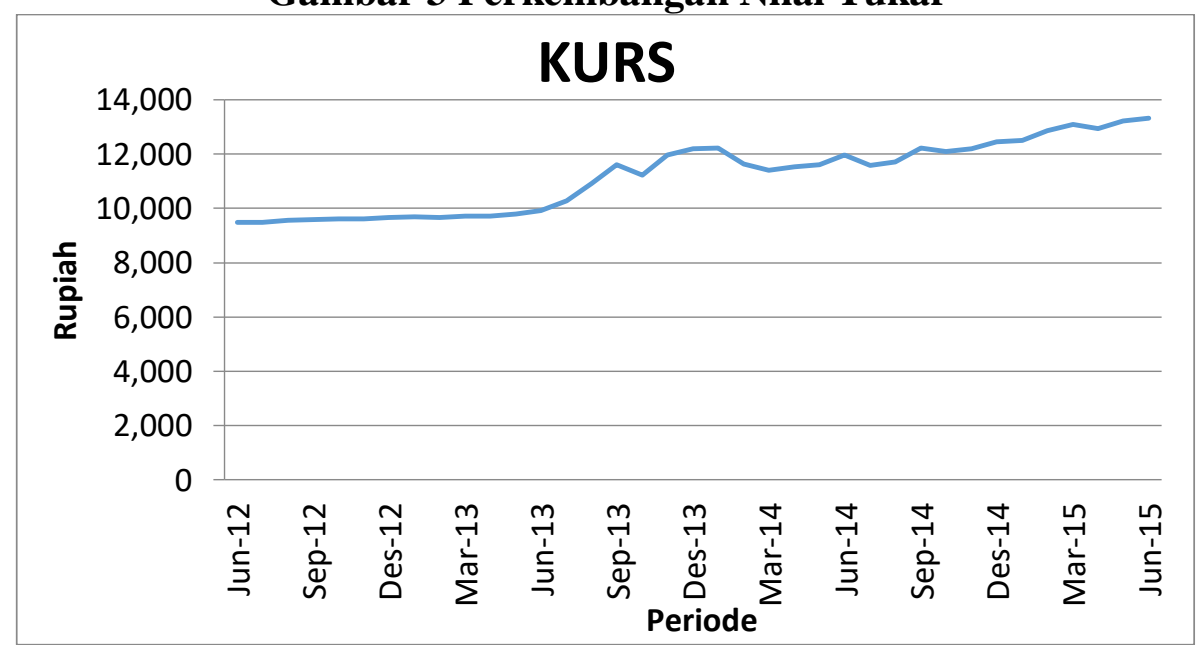

Sumber: Bank Indonesia (Olahan peneliti)

Gambar 3 di atas dapat diketahui bahwa perkembangan kurs tertinggi terjadi pada bulan Juni 2015 sebesar Rp.13.332 dan terendah terjadi di bulan Juni 2012 sebesar Rp. 9.480. Sejak tahun 2012 rupiah cenderung bergerak melemah sejalan dengan ketidakpastian ekonomi global. 


\section{Perkembangan BI rate}

Gambar 4 Perkembangan BI Rate

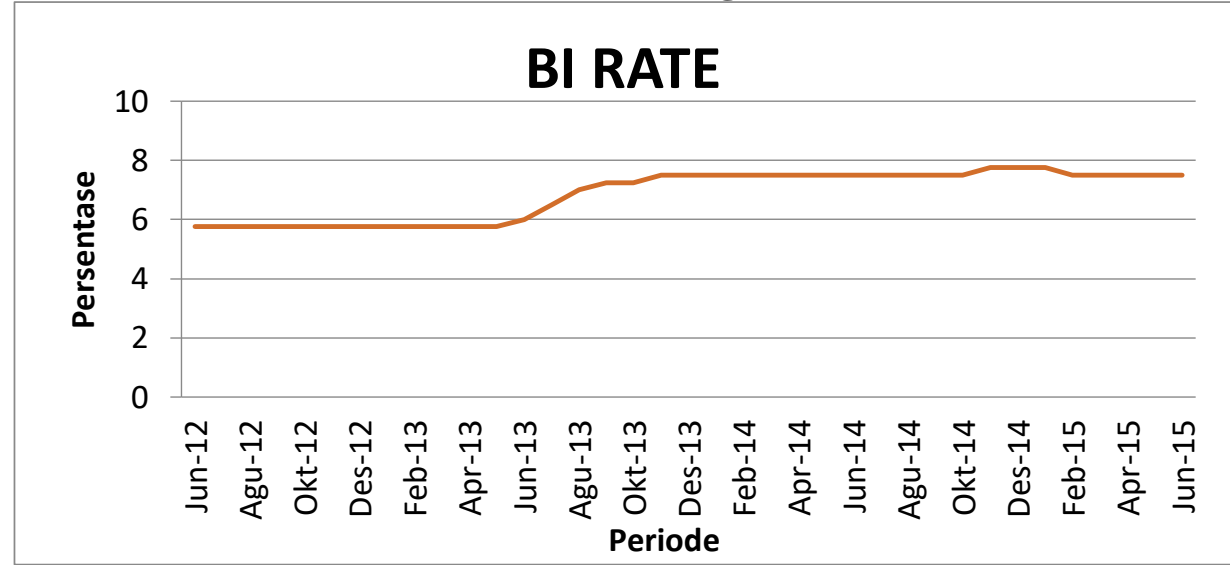

Sumber: Bank Indonesia (Olahan peneliti)

Gambar 4 di atas dapat diketahui bahwa perkembangan BI rate tertinggi terjadi pada bulan November 2014 sampai Febuari 2015 sebesar 7,75 \% dan terendah terjadi di bulan Juni 2012 sampai dengan Mei 2013 sebesar 5,75\%. Selama tahun 2012 sampai dengan tahun 2014 berakhir, BI rate cenderung terus mengalami kenaikan secara bertahap, hingga yang tertinggi terjadi pada bulan November 2014 yang mencapai 7,75 \%. Meskipun di awal tahun 2015 BI rate masih berada di level 7,75 \% tetapi secara bertahap pada tahun 2015 BI rate mulai berangsur turun hingga pada bulan Juni 2015 BI rate berada di level 7,50\%.

\section{Uji Normalitas}

Uji normalitas data dilakukan untuk mengetahui bahwa residual berdistribusi normal atau tidak normal. Menentukan apakah residual berdistribusi normal atau tidak normal. Dalam penelitian ini analisis uji normalitas data menggunakan grafik normalitas residual (Normal P-P Plot of Regression Standardized Residual).

\section{Gambar 5 Hasil Uji Normalitas}

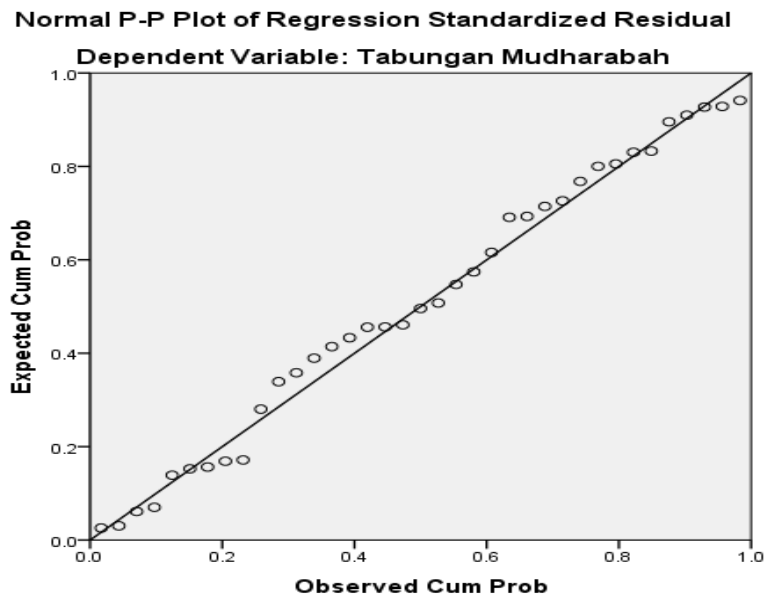

Sumber: Output SPSS 
Berdasarkan gambar 5 di atas, diketahui bahwa data atau titik-titik menyebar disekitar garis diagonal (tidak terpencar jauh dari garis lurus), maka dapat dikatakan bahwa data variabel memiliki residual yang berdistribusi normal. Dengan demikian asumsi yang menyatakan bahwa model regresi harus memiliki residual berdistribusi normal dapat dipenuhi.

\section{Uji Heterokedastisitas}

Uji heteroskedastisitas bertujuan menguji model regresi yang menunjukkan ada tidaknya kesamaan varians dari satu residual pengamatan ke pengamatan yang lain. Jika varians dari residual satu pengamatan ke pengamatan yang lain tetap, maka disebut homoskedastisitas, dan jika berbeda disebut heteroskedastisitas. Model regresi yang baik adalah yang homokedastisitas atau tidak terjadi Heteroskedastisitas. Untuk mengetahui ada tidaknya Heteroskedastisitas dengan melihat grafik scatterplot. Dasar analisisnya, jika ada pola tertentu seperti titik-titik yang ada membentuk pola tertentu yang teratur (bergelombang, menyebar kemudian menyempit), maka mengindikasikan telah terjadi heteroskedastisitas. Sebaliknya jika tidak ada pola yang jelas serta titiktitik menyebar di atas dan di bawah angka 0 pada sumbu Y, maka tidak terjadi heteroskedastisitas.

\section{Gambar 6 Hasil Uji Heterokedastisitas}

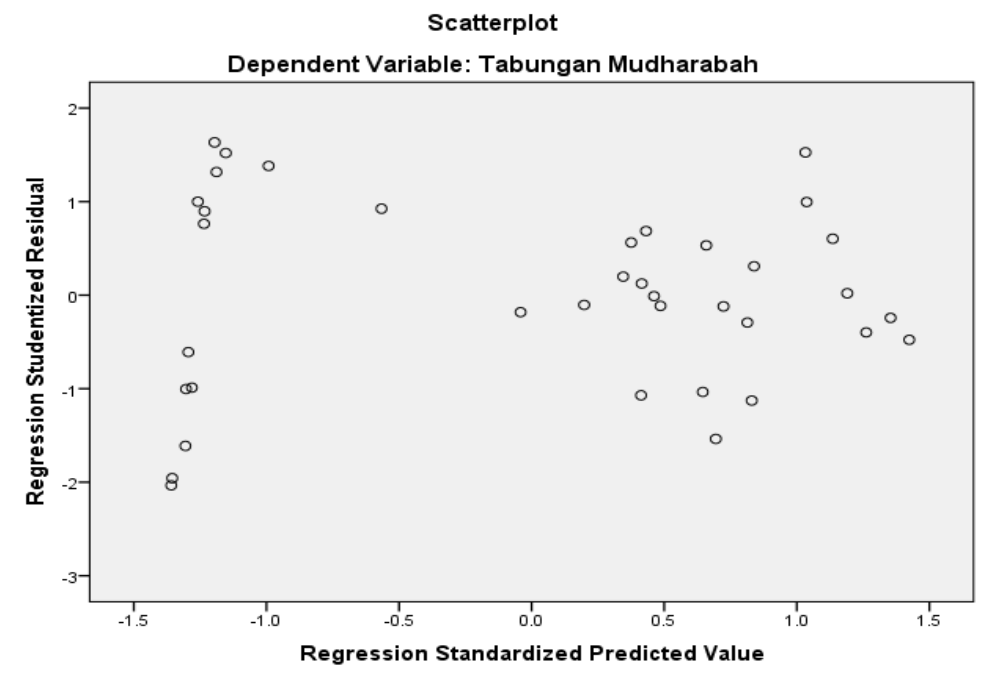

Sumber: Output SPSS

Berdasarkan gambar 6 scatterplot terlihat bahwa titik-titik menyebar secara acak serta tersebar baik di atas maupun di bawah angka 0 pada sumbu Y. Dengan demikian dapat disimpulkan tidak terjadi heteroskedastisitas pada model regresi. Dengan demikian asumsi yang menyatakan bahwa dalam model regresi tidak terjadi heteroskedastisitas dapat dipenuhi.

\section{Uji Multikolinearitas}

Uji multikolinieritas bertujuan untuk menguji apakah model regresi ditemukan adanya korelasi antar variabel bebas. Model regresi yang baik seharusnya tidak terjadi korelasi di antara variabel bebas. Kriteria yang digunakan adalah jika nilai VIF tidak lebih dari angka 10 dan tidak memiliki nilai 
tolerance kurang dari 0,10 , maka dikatakan tidak terdapat masalah multikolinieritas dalam model regresi berganda.

\section{Tabel 1 Hasi Uji Multikolininieritas}

Coefficients $^{a}$

\begin{tabular}{|c|c|c|c|}
\hline & \multirow{2}{*}{ Model } & \multicolumn{2}{|c|}{ Collinearity Statistics } \\
\hline & & Tolerance & VIF \\
\hline \multirow{3}{*}{1} & Inflasi & ,660 & 8,515 \\
\hline & Kurs Rp &, 524 & 8,055 \\
\hline & BI Rate & ,512 & 8,919 \\
\hline
\end{tabular}

a. Dependent Variable: Tabungan Mudharabah

Sumber: Output SPPS

Berdasarkan tabel $1 \mathrm{di}$ atas dapat diketahui nilai tolerance variabel inflasi sebesar 0,660, nilai tolerance variabel nilai tukar atau kurs rupiah sebesar 0,524 dan nilai tolerance variabel BI Rate sebesar 0,512. Nilai VIF variabel inflasi sebesar 8,515, dan nilai VIF variabel Kurs Rupiah sebesar 8,055 nilai VIF variabel BI Rate sebesar 8,919. Dengan demikian, dapat dikatakan bahwa dalam model regresi antara variabel bebas inflasi $\left(\mathrm{X}_{1}\right)$, Kurs Rupiah $\left(\mathrm{X}_{2}\right)$ dan BI Rate $\left(\mathrm{X}_{3}\right)$ tidak terjadi multikolonieritas.

\section{Uji Autokorelasi}

Autokorelasi adalah suatu keadaan dimana terjadi korelasi antara residual tahun ini dengan tingkat kesalahan tahun sebelumnya. Untuk mengetahui ada atau tidaknya penyakit autokorelasi dalam suatu model, dapat dilihat dari nilai statistik Durbin-Watson.

\section{Tabel 2 Uji Durbin-Watson} Model Summary ${ }^{b}$

\begin{tabular}{lccc}
\hline Model & $\mathrm{R}$ & $\mathrm{R}$ Square & Durbin-Watson \\
\hline 1 &, $946^{\mathrm{a}}$ &, 895 & 1,554 \\
\hline a. Predictors: (Constant), BI Rate, Inflasi, Kurs Rp \\
b. Dependent Variable: Tabungan Mudharabah \\
Sumber: Output SPSS
\end{tabular}

Berdasarkan tabel 2 di atas diketahui nilai Durbin-Watson $(D W)$ sebesar 1,554. Oleh karena nilai DW berada di atas 1 dan lebih kecil dari $3(1<1,554<3)$, maka tidak ada autokorelasi. Dengan demikian, dapat dikatakan bahwa dalam model regresi tidak terjadi autokorelasi.

\section{Uji Linearitas}

Uji linieritas model regresi antara variabel bebas $\mathrm{X} 1, \mathrm{X} 2$ dan $\mathrm{X} 3$ dengan variabel terikat Y menggunakan grafik scatterplot. Kriteria jika sebaran data akan berada mulai dari kiri bawah lurus ke arah kanan atas maka dapat dikatakan data membentuk garis linier, dan sebaliknya jika sebaran data tidak menyebar dari kiri bawah lurus ke arah kanan atas maka dapat dikatakan data tidak membentuk garis linier. 


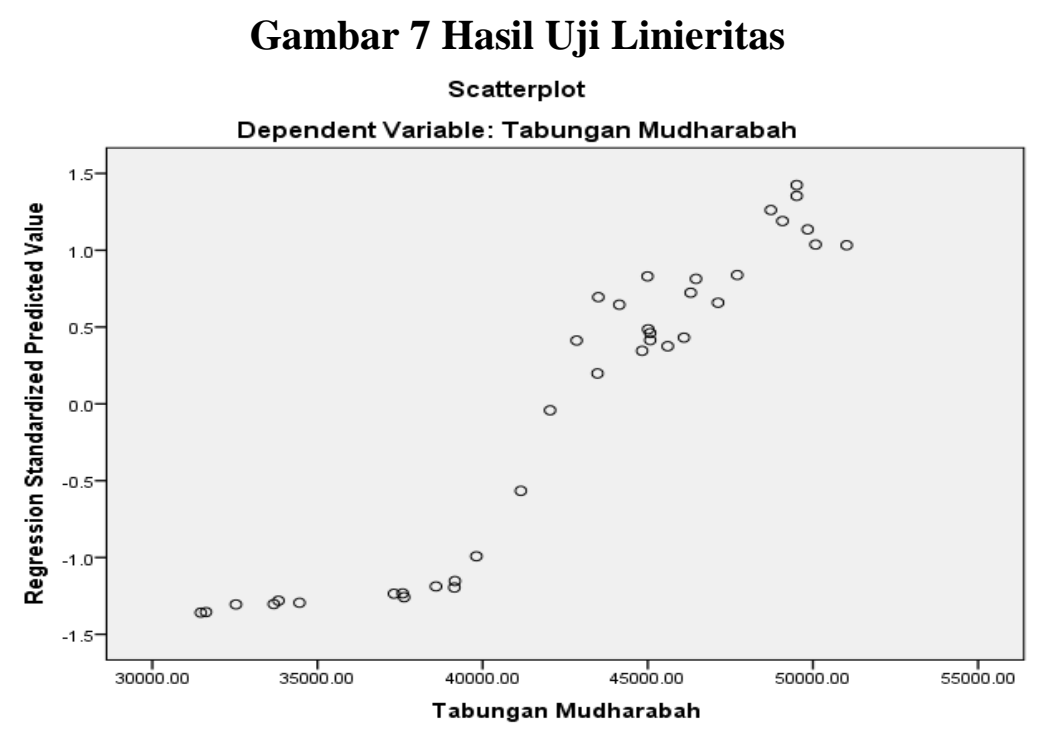

Sumber: Output SPSS

Berdasarkan gambar 7 di atas, terlihat sebaran data membentuk arah garis lurus dari kiri bawah ke kanan atas. Dengan demikian dapat dikatakan bahwa model regresi mempunyai bentuk yang linier. Oleh karena itu asumsi model regresi harus linier sudah terpenuhi.

\section{Uji Regresi Berganda}

Tabel 3 Hasil Koefisien Regresi Berganda Coefficients $^{\mathrm{a}}$

\begin{tabular}{|c|c|c|c|c|c|c|}
\hline & \multirow{2}{*}{ Model } & \multicolumn{2}{|c|}{$\begin{array}{c}\text { Unstandardized } \\
\text { Coefficients }\end{array}$} & \multirow{2}{*}{$\begin{array}{c}\text { Standardized } \\
\text { Coefficients } \\
\text { Beta }\end{array}$} & \multirow{2}{*}{$t$} & \multirow{2}{*}{ Sig. } \\
\hline & & $\boldsymbol{B}$ & $\begin{array}{l}\text { Std. } \\
\text { Error }\end{array}$ & & & \\
\hline \multirow{4}{*}{1} & (Constant) & $-4022,021$ & 2813,933 & & $-1,429$ &, 162 \\
\hline & Inflasi & 145,198 & 254,831 & ,139 & 3,570 &, 003 \\
\hline & Kurs Rp & 3,036 & ,707 & ,686 & 4,295 &, 000 \\
\hline & BI Rate & 1706,790 & 1148,103 &, 250 & 3,487 &, 007 \\
\hline
\end{tabular}

Sumber: Output SPSS

Berdasarkan tabel 3 di atas, maka didapat model persamaan regresi berganda yaitu: $\mathrm{Y}=-4022,021+145,198 \mathrm{X}_{1}+3,036 \mathrm{X}_{2}+1706,790 \mathrm{X}_{3}$. Nilai konstan (a) $=-4022,021$. Artinya bahwa besarnya nilai prediksi (Y) sebesar 4022,021 jika variabel bebas $X_{1}, X_{2}$ dan $X_{3}=0$. Hal ini berarti bahwa, jika tidak dipengaruhi inflasi, nilai tukar atau kurs rupiah dan BI Rate, maka nilai prediksi tabungan mudharabah sebesar $\mathrm{X}_{2}$. Nilai koefisien regresi inflasi $\left(\mathrm{X}_{1}\right)$ positif sebesar 145,198. Artinya, jika koefisien inflasi $\left(X_{1}\right)$ berubah satu satuan, maka tabungan mudharabah (Y) akan berubah sebesar 145,198 kali satuan dengan asumsi bahwa variabel lainnya tetap atau konstan. Nilai koefisien regresi nilai tukar atau kurs rupiah $\left(\mathrm{X}_{2}\right)$ positif sebesar 3,036. Artinya, jika koefisien regresi nilai tukar atau kurs rupiah $\left(\mathrm{X}_{2}\right)$ berubah satu satuan, maka tabungan mudharabah (Y) akan berubah sebesar 3,036 kali satuan dengan asumsi bahwa variabel lainnya 
tetap atau konstan. Nilai koefisien regresi BI Rate $\left(\mathrm{X}_{3}\right)$ positif sebesar 1706,790. Artinya, jika koefisien regresi $\mathrm{BI}$ Rate $\left(\mathrm{X}_{3}\right)$ berubah satu satuan, maka tabungan mudharabah (Y) akan berubah sebesar 1706,790 kali satuan dengan asumsi bahwa variabel lainnya tetap atau konstan.

\section{Uji Parsial (Uji t)}

Berdasarkan tabel 3, kolom t didapat nilai $t_{\text {hitung }}$ inflasi sebesar 3,570 dan nilai kolom sig didapat nila sig sebesar 0,003 . Oleh karena nilai $t_{\text {hitung }}>t_{\text {tabel }}$ atau $3,570>2,021$ serta nilai $0,003<0,05$, maka hipotesis pertama diterima. Hal ini menyatakan bahwa secara statistik terbukti inflasi berpengaruh terhadap tabungan mudharabah pada perbankan syariah. Nilai standardized coefficients atau beta, sebesar 0,139, ini menunjukkan bahwa inflasi berpengaruh positif terhadap tabungan mudharabah pada perbankan syariah. Nilai positif berarti jika ada pengaruh-pengaruh positif dari inflasi, maka akan meningkatkan tabungan mudharabah pada perbankan syariah di Indonesia.

Nilai $t_{\text {hitung }}$ kurs sebesar 4,295 dan nilai sig sebesar 0,000. Oleh karena nilai $t_{\text {hitung }}>t_{\text {tabel }}$ atau 4,295 $>2,021$ serta nilai $0,000<0,05$, maka hipotesis kedua diterima. Hal ini menyatakan bahwa secara statistik terbukti nilai tukar atau kurs rupiah berpengaruh terhadap tabungan mudharabah pada perbankan syariah. Nilai standardized coefficients atau beta, sebesar 0,686, ini menunjukkan bahwa nilai tukar atau kurs rupiah berpengaruh positif terhadap tabungan mudharabah pada perbankan syariah. Nilai positif berarti jika ada pengaruh-pengaruh positif dari kurs rupiah, maka akan meningkatkan tabungan mudharabah pada perbankan syariah di Indonesia.

Nilai $t_{\text {hitung }}$ BI Rate sebesar 3,487 dan nilai sig sebesar 0,007. Oleh karena nilai $t_{\text {hitung }}>\mathrm{t}_{\text {tabel }}$ atau 3,487 $>2,021$ serta nilai $0,007<0,05$, maka hipotesis ketiga diterima. Hal ini menyatakan bahwa secara statistik terbukti BI Rate berpengaruh terhadap tabungan mudharabah pada perbankan syariah. Nilai standardized coefficients atau beta, sebesar 0,259, ini menunjukkan bahwa BI Rate berpengaruh positif terhadap tabungan mudharabah pada perbankan syariah. Nilai positif berarti jika ada pengaruh-pengaruh positif dari BI Rate, maka akan meningkatkan tabungan mudharabah pada perbankan syariah di Indonesia.

\section{Uji Simultan (Uji F)}

Uji $\mathrm{F}$ adalah pengujian yang dilakukan untuk mengetahui ada atau tidaknya pengaruh dari variabel bebas (X1, X2 dan X3) secara simultan terhadap variabel terikat (Y).

Tabel 4 ANOVA ${ }^{a}$

\begin{tabular}{llccccc}
\hline & Model & Sum of Squares & df & Mean Square & $\boldsymbol{F}$ & Sig. \\
\hline \multirow{4}{*}{1} & Regression & 1056635186,998 & 3 & 352211728,999 & 94,131 &, $000^{\mathrm{b}}$ \\
& Residual & 123476569,975 & 33 & 3741714,242 & & \\
& Total & 1180111756,973 & 36 & & & \\
\hline
\end{tabular}

a. Dependent Variable: Tabungan Mudharabah

b. Predictors: (Constant), BI Rate, Inflasi, Kurs Rp

Sumber: Output SPSS

Berdasarkan tabel 4, nilai $F$ diperoleh nilai $F_{\text {hitung }}$ sebesar 94,131 serta nilai sig sebesar 0,000. Oleh karena nilai $F_{\text {hitung }}>F_{\text {tabel }}$, atau 94,131 $>2,89$ serta 
nilai sig $0.000<0.05$, hipotesis keempat diterima, ini menyatakan bahwa secara statistik terbukti ada pengaruh antara inflasi, nilai tukar atau kurs rupiah dan BI Rate secara simultan terhadap tabungan mudharabah pada perbankan syariah di Indonesia.

\section{Uji Koefesien Determinasi}

Tabel 5 Model Summary ${ }^{b}$

\begin{tabular}{ccccc}
\hline Model & $\boldsymbol{R}$ & $\boldsymbol{R}$ Square & $\begin{array}{c}\text { Adjusted } \boldsymbol{R} \\
\text { Square }\end{array}$ & $\begin{array}{c}\text { Std. Error of the } \\
\text { Estimate }\end{array}$ \\
\hline 1 &, $946^{\mathrm{a}}$ &, 895 &, 886 & 1934,35112 \\
\hline
\end{tabular}

a. Predictors: (Constant), BI Rate, Inflasi, Kurs Rp

b. Dependent Variabel: Tabungan Mudharabah

Sumber: Output SPSS

Berdasarkan tabel 5 di atas, dapat diketahui hasil bahwa nilai $R$ sebesar 0,946, ini menunjukkan bahwa korelasi antara inflasi, nilai tukar atau kurs rupiah dan BI Rate secara simultan dengan tabungan mudharabah pada perbankan syariah adalah sangat kuat. Nilai Adjusted $R$ Square sebesar 0,886 menunjukkan bahwa pengaruh inflasi, nilai tukar atau kurs rupiah dan BI Rate secara simultan terhadap tabungan mudharabah pada perbankan syariah di Indonesia sebesar 88,6\% sedangkan sisanya sebesar $11.4 \%$ adalah kontribusi variabel lain diluar penelitian.

\section{KESIMPULAN}

Berdasarkan pengujian secara parsial bahwa secara statistik variabel inflasi berpengaruh positif terhadap tabungan mudharabah pada perbankan syariah di Indonesia. Variabel nilai tukar atau kurs rupiah berpengaruh positif tabungan mudharabah pada perbankan syariah di Indonesia. Variabel BI Rate berpengaruh positif terhadap tabungan mudharabah pada perbankan syariah di Indonesia. Secara simultan variabel inflasi, nilai tukar atau kurs rupiah dan BI Rate mempunyai pengaruh signifikan terhadap tabungan mudharabah pada perbankan syariah di Indonesia dengan besar pengaruh sebesar 88,6\%.

\section{DAFTAR PUSTAKA}

Al-Arif, M. Nur Rianto. 2010. Teori Makroekonomi Islam: Konsep, Teori dan Analisis. Bandung: Alphabeta.

Amin, Nurul. 2012. "Dampak Kebijakan Fiskal Terhadap Output Dan Inflasi”. IQTISHADUNA: Jurnal Ilmiah Ekonomi Kita 1 (1), 69-98.

Ariestantya, Dian. 2011. "Analisis Pengaruh Imbal Bagi Hasil, Jumlah Kantor Cabang, Suku Bunga, Kurs, dan SWBI terhadap Jumlah Tabungan Mudharabah". Jakarta.

Bahri, Saipul. 2016. Untuk Menggapai Karunia Tuhanmu. Yogyakarta: Deepublish. 
Bank Indonesia. 2016. Informasi Dasar: Suku Bunga. Diakses dari: http://www.bi.go.id/, tanggal 12 Februari 2016.

Depdikbud. 1989. Kamus Besar Bahasa Indonesia. Jakarta: Balai Pustaka.

Hermansyah. 2011. Hukum Perbankan Nasional Indonesia. Jakarta: Kencana.

Ishak, Khodijah. 2014. "Maqashid Syariah Dan Maslahah Dalam Ekonomi Dan Bisnis Syariah". IQTISHADUNA: Jurnal Ilmiah Ekonomi Kita 3 (1), 659673.

Ismail. 2011. Perbankan Syariah. Jakarta: Kencana.

Junery, Muhammad Fadhil. 2012. "Konsep Moneter Islam Solusi Terhadap Penanggulangan Goncangan (Shock) Ekonomi”. IQTISHADUNA: Jurnal Ilmiah Ekonomi Kita 1 (1), 99-116.

Karim, Adiwarman A. 2010. Bank Islam: Analisis Fiqih dan Keuangan. Jakarta: PT Raja Grafindo Persada.

Karim, Adiwarman A. 2014. Ekonomi Makro Islami. Jakarta: Rajawali Pers.

Kementerian Agama RI. 2010. Syaami Quran: Bukhara Tajwid dan Terjemahan, Al-quran Tadwid dan Terjemahan. Jakarta.

Maruta, Heru. 2016. "Akad Mudharabah, Musyarakah, Dan Murabahah Serta Aplikasinya Dalam Masyarakat". IQTISHADUNA: Jurnal Ilmiah Ekonomi Kita 5 (2), 80-106.

Misbahuddin dan Iqbah Hasan. 2013. Analisis Data Penelitian Dengan Statistik. Jakarta: PT Bumi Aksara.

Muhammad. 2014. Manajemen Dana Bank Syariah. Jakarta: Rajawali Pers.

Muslich, Achmad Wardi. 2015. Fiqih Muamalat. Jakarta: Amzah.

Nasution, Mustasfa Edwin, et al. 2010. Pengenalan Eksklusif: Ekonomi Islam. Jakarta: Kencana.

OJK. 2015. Statistik Perbankan Syariah di Indonesia Tahun 2015. http://www.ojk.go.id.

Rachmad, Dedy. 2013. "Pemilihan Institusi Perbankan Syariah Di Kalangan Masyarakat Muslim Indonesia". IQTISHADUNA: Jurnal Ilmiah Ekonomi Kita 2 (1), 396-403.

Rahardja, Prathama. 2008. Pengantar Ilmu Ekonomi (Mikro Ekonomi dan Makro Ekonomi). Jakarta: Lembaga Penerbit Fakultas Ekonomi Universitas Indonesia.

Siregar, Sofyan. 2013. Metode Penelitian Kuantitatif. Jakarta: Kencana.

Siregar, Sofyan. 2015. Statistik Parametrik Untuk Penelitian Kuantitatif. Jakarta: PT Bumi Aksara.

Sujarweni, V. Wiratna. 2015. Statistik Untuk Bisnis dan Ekonomi. Yogyakarta: Pustaka Baru Press.

Sukirno, Sadono. 2011. Makro Ekonomi Teori Pengantar. Jakarta: PT Raja Grafindo Persada.

Supriyono, Maryanto. 2011. Buku Pintar Perbankan. Yogyakarta: Andi.

Suharyanti. 2010. "Analisis Pengaruh Nisbah Bagi Hasil, Inflasi, Pendapatan Nasional/PDB, dan SWBI Terhadap Tabungan Mudharabah Pada Perbankan Syariah Di Indonesia". Jakarta: Jurusan Ilmu Ekonomi dan Studi Pembangunan, Fakultas Ekonomi dan Bisnis UIN Syarif Hidayatullah.

Wahana Komputer. 2012. 10 Model Penelitian dan Pengolahannya Dengan SPSS 14, Edisi IV. Yogyakarta: Andi. 